\title{
A Dangerous Chimera: Anti-suit Injunctions based on a "right to be sued" at the place of domicile under the Brussels la Regulation?
}

It has often been observed that the brocard ubi jus, ibi remedium might, for a cross border private lawyer, read ubi remedium, ibi jus. Lord Rodger of Earlsferry, however, rejected the inverted principle of ubi remedium ibi ius as "unsafe" in Harding v Wealands [2006] UKHL 32, [2007] 2 AC 1 at [76]. In the Court of Appeal decision under consideration, it will be argued that the appellant's argument adheres to the creative spirit of the former but crucially ignores the cautionary and principled stance of the latter.

At the outset, it should be noted that the Brussels la Regulation (2012) is a multilateral jurisdiction and judgments instrument where the rules on jurisdiction resemble public law rules allocating adjudicatory authority as opposed to giving rise to private law rights and obligations inter partes. If a substantive right to be sued in a Member State court could even possibly be derived from a rule of jurisdiction under Brussels la, it is uncertain whether such a right could constitute the proper legal basis of an anti-suit injunction. As this is a single forum case, an anti-suit injunction would not only infringe comity but would also deny access to justice in the only available forum.

In Gray v Hurley [2019] EWCA Civ 2222, the Court of Appeal (Patten, Hickinbottom and Peter Jackson LJ), handed down the judgment on the claimant's appeal in [2019] EWHC 1972 (QB). The appellant appealed against the refusal of an anti-suit injunction.

The appellant (Ms Gray) and respondent (Mr Hurley) had been in a relationship. They acquired property in various jurisdictions using the appellant's money, but held it in either the respondent's name or in corporate names. The relationship ended and a dispute commenced over ownership of some of the assets. The appellant was domiciled in England; the respondent lived in New Zealand after the relationship ended and was no longer domiciled in England. He initiated proceedings there for a division of the property acquired by the couple during the relationship. The appellant issued proceedings in England seeking a declaration that she was entitled absolutely to the assets. She also applied for an anti-suit injunction to restrain the respondent from continuing with proceedings in New Zealand. Lavender J rejected her argument that Article 4(1) of the Brussels la Regulation obliged him to grant an anti-suit injunction to prevent the respondent from litigating in New Zealand.

The appellant argued that Samengo-Turner v J\&H Marsh \& McLennan (Services) Ltd [2007] EWCA Civ 723, [2007] 2 All E.R. (Comm) 813 ("Samengo-Turner") and Petter v EMC Europe Ltd [2015] EWCA Civ 828, [2015] C.P. Rep. 47 ("Petter") were binding authority that Article 4(1) provided her with a right 
not to be sued outside England, where she was domiciled, obliging the court to enforce that right with an anti-suit injunction.

The Court of Appeal considered that the issue was not acte claire and sent a preliminary reference to the CJEU under Article 267 TFEU asking:

Does Article 4(1) confer a directly enforceable right upon a person domiciled in a Member State?

If it does,

Where such a right is breached by the bringing of proceedings against that person in a third State, is there an obligation upon the Member State to provide a remedy, including by the grant of an anti-suit injunction?

Does any such obligation extend to a case where a cause of action available in the courts of a third State is not available under the law applicable in the courts of the Member State?

Both Samengo-Turner and Petter, examined the current Article 22(1) of the Brussels la Regulation. In the present case, the issue is whether that reasoning extends beyond the context of the decisions, namely employment contracts, so that it is generally applicable, including to cases falling under Article 4(1).

The appellant argued that the ratio of Samengo-Turner and Petter is not limited to the proposition that English-domiciled employees should have their right to be sued by their employer in England protected by an anti-suit injunction. She submitted that the case also establishes the broader proposition that a person with a right to be sued in England should almost invariably have that right protected by an anti-suit injunction. It is submitted that the law does not permit so wide a proposition. The argument against this novel interpretation of the law is even stronger where the cause of action in the third State jurisdiction could not be brought in England.

The decisions in Samengo-Turner and Petter have been the subject of trenchant criticism by commentators. A Dickinson (2008) 57 I.C.L.Q. 465, 470-471, argued that the suggestion that the Brussels la Regulation creates rights and obligations between individuals is inconsistent with its legislative history. The Regulation only creates rules of a procedural character. Such rules only govern relations between private litigants indirectly by prescribing the jurisdiction of Member State courts in civil and commercial matters. The rules of jurisdiction in the Regulation can only be understood as directions to Member State courts as to when they are obliged or permitted to accept or decline jurisdiction. Any provisions of the Regulation using the language of obligation should only 
This is a pre-copyedited, author-produced version of an article accepted for publication in the Law Quarterly Review following peer review. The definitive published version will be available online on Westlaw UK or from Thomson Reuters DocDel service

extend to Member States' judicial authorities. It has also been argued that in Hohfeldian terms, 'the right not to be sued' in a particular court created by the Brussels la Regulation, is actually a privilege combined with an immunity, not a right which imposes a private law duty not to sue elsewhere. See T Raphael [2016] L.M.C.L.Q. 256, 266; See generally, WN Hohfeld (1913) 23 Yale Law Journal 16.

In the context of choice of court agreements under Article 25 of the Brussels la Regulation, this author has argued elsewhere that the contractual duty not to be sued in a non-elected forum and the correlative right to sue only in the contractual forum are intrinsically incompatible with the system of the international public ordering of private law affected by the Regulation. See M Ahmed, The Nature and Enforcement of Choice of Court Agreements (2017) 77-82. A Briggs [2016] L.M.C.L.Q. 236, 248, argued that in Hohfeldian terms a party waives the jurisdictional privilege of being sued where he is domiciled and assumes a jurisdictional liability to be sued, in relation to which the claimant acquires a correlative power to sue him, in the chosen court.

It is submitted that the preceding arguments are persuasive and suggest that Samengo-Turner and Petter were themselves wrongly decided. The opinion of AG Jääskinen in Hydrogen Peroxide SA v Akzo Nobel NV (C-352/13) EU:C:2014:2443, also emphasized the subsidiary nature of EU procedural law and suggested that it did not impose rights and obligations on parties.

Notwithstanding these fundamental criticisms, Samengo-Turner and Petter can be distinguished from the present case. A verbatim transplant of the underpinning legal reasoning from Article 22 to Article 4 presupposes the existence of significant similarities between the two provisions. However, no consideration was given to the question of why the protection given by Article 4 should be considered to be the same as that provided by Article 22 when Recital 18 specifies that for an employee there should be "rules of jurisdiction more favourable to his interests than the general rules". It should be noted that jurisdiction under Article 4 is "mandatory" but it is not considered "exclusive" in the hierarchy of jurisdictional rules of the Brussels la Regulation. The CJEU's decision in Owusu v Jackson (C-281/02) EU:C:2005:120 ("Owusu") establishes that the court of a Member State may not decline jurisdiction but it does not establish a further requirement preventing the commencement or continuation of proceedings in another jurisdiction. Article 22, however, makes explicit that jurisdiction in employment situations is "exclusive".

The decisions in Samengo-Turner and Petter are properly situated in the law relating to employment contracts. The learned editors of Dicey, Morris and Collins, Conflict of Laws (2012) also treat the decision in Samengo-Turner as being restricted to employment cases (12-022). Employment contracts are asymmetric contracts where the employee is a weaker party in relation to the 
This is a pre-copyedited, author-produced version of an article accepted for publication in the Law Quarterly Review following peer review. The definitive published version will be available online on Westlaw UK or from Thomson Reuters DocDel service

employer. This justifies the specific treatment of employment contracts in Section 5 of the Brussels la Regulation. The general jurisdictional rules in Section 1 cover a much wider range of civil and commercial matters and will give rise to a different range of considerations.

The appellant claimed that the Regulation does not merely lay down procedural rules but confers enforceable rights. She relied on Group Josi Reinsurance Company SA v Universal General Insurance Company (C-412/98) EU:C:2000:399; Owusu; Hypotecni Bank v Lindner (C - 327/10) EU:C:2011:745 and Vedanta $v$ Lungowe [2019] UKSC 20. It is submitted that none of these decisions are concerned with a privately enforceable 'right not to be sued' in a particular forum which prevents the commencement or continuation of proceedings in another jurisdiction.

As to the nature and enforceability of rights arising under the Regulation, Potter $\mathrm{J}$ observed in The Eras Eil Actions (No.2) [1995] 1 Lloyd's Rep 64 at 74-76, that it was not helpful to characterise commencement of a suit elsewhere as the invasion of a right. In fact, Potter J rejected the conclusion that an anti-suit injunction to restrain proceedings in the USA could be founded on a "right" to be sued only according to the rules of the Brussels Regime. In similar vein, Andrew Smith J in Evialis S.A. v S.I.A.T. [2003] EWHC 863 (Comm), [2003] 2 Lloyd's Rep 377 at [139(ii)], noted that injunctive relief cannot be ordered to enforce rights conferred by a Regulation when that relief is "outwith the machinery of the Regulation". This inherent disjuncture between a right conferred by an EU Regulation and its enforcement by a controversial English common law remedy arises because an anti-suit injunction is not a general characteristic of civil law legal systems, and is therefore not available before most Member State courts. Moreover, in Turner v Grovit (C-159/02) EU:C:2004:228, the CJEU held that the anti-suit injunction is not available as between Member State courts. In so holding, it observed that the anti-suit injunction is tantamount to interference with the civil jurisdiction of another Member State court and is incompatible with the principles of mutual trust and effet utile.

In Samengo-Turner and Petter there was a choice of jurisdictions in which the parties could litigate about the same cause of action. In the present case, the English court's exercise of discretion in granting an anti-suit injunction should be cognizant that this is a single forum case and any indirect interference with the jurisdiction of the New Zealand court would not only infringe comity but would also deny access to justice only available in that forum.

In refusing the anti-suit injunction, Lavender J correctly decided that a "breach" of Article 4(1) of Brussels la is not a significant factor in the exercise of his discretion to grant the remedy. Instead, he referred to the principles established in Deutsche Bank v Highland Crusader [2009] EWCA Civ 725, 
[2010] 1 WLR 1023 at [50]. In doing so, he held that England was the appropriate forum for the trial but the New Zealand claim could not be determined in England. An anti-suit injunction would prevent Mr Hurley from bringing his claim at all. He rejected that there was no material connection between the parties and New Zealand. He did not accept that the New Zealand claims would be unconscionable or illegitimate. He recognised the role of comity and that a New Zealand court could still decline jurisdiction.

It has been observed that serious doubts in relation to the veracity of the decisions in SamengoTurner and Petter persist among commentators. In light of this, it will be even more difficult to justify the broader application of a similar result in the present case. Indeed, it would be difficult to "fit" the present case into the aberrational foundations of the developing law on anti-suit injunctions based on rights derived from the Brussels la Regulation because a better "justification" for the law based on sound principle can be found. See generally, R Dworkin (1975) 88 Harvard Law Review 1057. A justification that does not create a fictitious right as the basis of a chimerical remedy that infringes comity and denies the respondent access to justice in the only available forum.

It is also likely that the reference sent to the CJEU, in the twilight of the Brussels la Regulation, will offer no reassurance to those seeking to derive a horizontally enforceable "right" from the general rule on jurisdiction in Brussels la to justify a familiar remedy. In the EU, remedies are generally regarded as being a matter of Member State law. However, the CJEU has established that all remedies normally available under national law must be available to litigants to enforce "rights" under EU law without discrimination. See TC Hartley, The Foundations of European Union Law (2014) 245-248. In the future, the English courts may also have to "pay due account" to the CJEU's decision in this case when interpreting Article 2 of the Lugano Convention (2007), which the UK government intends to accede to at the end of the post-Brexit transition period. 